\title{
DISSEMINAÇÃO DE CONHECIMENTO: NOSSO COMPROMISSO
}

A Associação Brasileira de Metalurgia, Materiais e Mineração - ABM -, ao longo de seus 73 anos de existência, presta um serviço à sociedade nas áreas de sua atuação, promovendo o desenvolvimento e disseminando conhecimento.

Há 13 anos, decidimos investir numa revista que pudesse divulgar os melhores trabalhos apresentados nos eventos produzidos e realizados pela Associação, e assim nasceu o periódico Tecnologia em Metalurgia, Materiais e Mineração - TMM. A publicação evoluiu e ganhou site e sistema de submissão próprios, passando a aceitar artigos também nos idiomas inglês e espanhol, de forma a que o conhecimento pudesse alcançar distâncias maiores, além dos limites da língua portuguesa.

O Professor Dr. André Luiz Vasconcelos da Costa e Silva, Editor chefe da TMM desde 2013, vem atuando ativamente, juntamente aos demais integrantes da revista, para que ela conquiste ainda mais reconhecimento nos segmentos de sua competência; e com iniciativa e dedicação, hoje nos orgulhamos de estar presentes nas mais renomadas bases indexadoras, tanto nacionais quanto internacionais.

E tudo isso, caro leitor, só é possível graças a sua contribuição e confiança no nosso trabalho! Esperamos ser cada vez mais merecedores dessa responsabilidade para que a nossa querida TMM perdure por muito e muitos anos. 